УДК: 930=161.2(043)

DOI: 10.31470/2518-7600-2019-8-55-75

CHARACTERISTICS OF THE SOURCES OF STUDY OF COUNTERFEIT COINS AND BANKNOTES IN THE MONETARY CIRCULATION IN UKRAINE IN THE IMPERIAL PERIOD (1795-1917)

\title{
ХАРАКТЕРИСТИКА ДЖЕРЕЛ ВИВЧЕННЯ ФАЛЬШИВИХ МОНЕТ ТА БАНКНОТ В ГРОШОВОМУ ОБІГУ УКРАЇНИ В ІМПЕРСЬКУ ДОБУ (1795-1917)
}

\section{ХАРАКТЕРИСТИКА ИСТОЧНИКОВ ИЗУЧЕНИЯ ФАЛЫШИВЫХ МОНЕТ И БАНКНОТ В ДЕНЕЖНОМ ОБРАЩЕНИИ УКРАИНЫ В ИМПЕРСКИЙ ПЕРИОД} (1795-1917)

Андрій Бойко-Гагарін, кандидат історичних наук, в.о. заступника генерального директора з розвитку e-mail:

boiko.gagarin@gmail.com ORCID 0000-0003-4610-3665 Національний музей історії України, вул.

Володимирська 2, м. Київ, 01001, Україна
Andrii Boiko-Gagarin, Ph.D. in historical science, deputy director of development e-mail:

boiko.gagarin@gmail.com ORCID 0000-0003-4610-3665 National Museum of History of Ukraine, Volodymyrska str. 2, Kyiv, 01001, Ukraine

\section{ABSTRACT}

Investigating of the processes of counterfeiting coins in Ukraine in the imperial period is possible using of a number of material, pictorial, behavioral and written sources. The main material source in the study of the chosen topic are the counterfeit of coins and banknotes. These artifacts, in turn, are stored in museum collections and private, sometimes contained as a material evidences in archival cases stitched as the separate sheets inside. The pages of cases of the State archives reveal various aspects of 
the investigated type of crime in the specified period have rather high value and considerable potential in studying of the topic of money counterfeiting. Although there are some disadvantages with the use of the newspaper periodicals, messages in the Imperial presses expand our understanding of the processes of counterfeiting. The published works of the previous researchers are stored in the holdings of libraries, as well as in private book collections are uploaded to the Internet bases and resources, also the personal pager in the social media for the scientists which are also useful when studying the topic. Fake coins sold at numismatic auctions are recorded in the relevant sales catalogs. Additional data provides researchers with photos and videos saved in the state historical archives.

Key words: Russian Empire, money forging, methodology of forgery discovery, archive materials, museum collections.

Постановка проблеми. Проблема приватної підробки грошей 3 моменту появи перших монет протягом століть залишалась гострою та актуальною для будь-якої державної влади. Упродовж всього періоду існування грошей як інструментів обігу, обміну, накопичення та платежу державою застосовувалися найрізноманітніші інструменти протидії їх фальшуванню. Аспект тогочасної підробки знаків грошової оплати включає вивчення особливостей появи тих чи інших прототипів підробок, питання економічних диверсій сусідніх держав, діяльність організованих злочинних груп фальшивомонетників, питання технологій виготовлення фальшивих монет i банкнот, їх державної експертизи та протидії з боку держави та правоохоронних органів, що визначає низку найрізноманітніших джерел. У статті надається характеристика основних джерел, що використовуються у процесі вивчення питань фальшування грошей в Україні в імперську добу (1795-1917), розглядається інформаційний та науковий потенціал кожного з видів джерел.

Аналіз останніх досліджень і публікацій. Окремі питання процесу підробки грошей у Російській імперії вивчались І. Колобовою (Колобова, 2015: 208), Н. Тімошиною (Тімошина, 2015: 200), А. Бойко-Гагаріним (Орлик, Бойко- 
Гагарін, 2017: 143-164), С. Орлик (Орлик, 2018-1: 35; Орлик, 2018-2: 51-54; Орлик, 2018-3: 761), а також В. Коцуром (Kotsur, Boiko-Gagarin, 2019: 66-77). Як бачимо, на сьогоднішній день процеси фальшування грошей в обігу України в імперську добу вивчені досить спорадично, що обумовлює високу актуальність надання детальної характеристики джерелам іï вивчення.

Мета статті. Визначити основні джерела вивчення процесів фальшування грошей в Україні в імперську добу (1795-1917), надавши їх характеристику та визначивши науковий потенціал.

Виклад основного матеріалу. Найбільш вдалою $\epsilon$ розроблена характеристика джерел авторського колективу на чолі з Я. Калакурою (Калакура, 2002). Так за типологією і способом кодування та відтворення інформації визначають: речові, писемні, усні, зображальні, звукові, поведінкові та конвенціональні джерела. За змістом виділено соціальноекономічні, політичні, правничі, культурологічні та релігійні джерела. За походженням - особові, колективні та, відповідно, до фондоутворювача.

У фокусі обраної теми нами досліджено речові джерела зразки підроблених тогочасних монет та кредитних білетів, а також інструменти (чи їх частини) для їх виготовлення. Відомим ученим Я. Калакурою справедливо зазначено, що монети, як речові джерела, також несуть ознаки зображального джерела, несучи на своєму полі зображення портретів, гербів, написів легенд та прикрас. Специфікою обраної нами теми дослідження $є$ порівняння відхилень у виконанні зображень на фальшивих грошах проти грошей державного виробництва, що зачіпає зображальні якості монети і визначає іiі як не лише речове, a і зображальне джерело. Серед речових джерел визначаються характерні для нашого дослідження нумізматичні та архітектурні. Архітектурними джерелами виступають приміщення, в яких проводилось фальшування грошей - старі будинки, підвали будинків, старі виробничі приміщення, про які повідомляється в писемних та документальних джерелах.

Зображальні джерела нами використані у вигляді фотографій фальшивомонетників із карних архівних справ, абриси та зображення фальшивих кредитних білетів у 
публікаціях та архівах. До зображальних джерел належать також паперові грошові знаки - боністичні джерела (у фокусі нашої теми підроблені кредитні білети та грошові сурогати).

Поведінковими джерелами у фокусі вивчення процесів фальшивомонетництва можуть вважатись дії, мотиви та вчинки злочинців, що займались незаконним виготовленням монети, а також чітко визначені інструкціями та нормативами дії щодо їх розслідування - пошуку, затримання, проведення експертизи вилучених підробок, судочинства тощо.

До писемних документальних джерел належать державні акти, грамоти, угоди, анкети, листи тощо. Під час вивчення процесів фальшування монет використано низку писемних джерел: актові матеріали та розпорядження влади щодо протидії фальшивомонетництва, анкети каторжників зі слідчих справ, збережених в архівах, листи нумізматів щодо виявлення підробок, а також переписки між карними органами 3 повідомленням про виявлення у регіоні фальшивих грошей до губернатора, органів судочинства та установ, що здійснюють експертизу виявлених підробок, викладених на аркушах паперу показання та матеріали допитів із слідчих справ, тощо. До писемних джерел також належить періодична преса (газети), що у досліджуваному періоді містить найрізноманітніші повідомлення про появу фальшивих монет, викриття та затримку фальшивомонетників, відмінні риси підроблених грошей, покарання злочинців тощо. У дослідженні процесів фальшування монет використовуються не лише газети українських губерній та міст, а також і повідомлення із газетних видань інших регіонів Російської імперії про Україну. Я. Калакурою підкреслено значну інформативність судовослідчих матеріалів що також широко використані нами у вивченні обраної теми. Судово-слідчі матеріали поділяються на: слідчі матеріали (протоколи обшуків, слідства, допитів, очних ставок, донесення агентів, листування слідчих органів), судові документи (протоколи судових засідань, допитні листи по справі, вироки судів) та матеріали прокурорського нагляду. Дійсно, судово-слідчі матеріали мають персоніфікований характер, розкривають біографічні факти щодо фальшивомонетників, допомагають встановити їх соціальний портрет (Калакура, 2002: 96-120). 
Виявлення під час дослідження джерел специфічної лексики, що використовувалась слідчими органами, експертами та простими громадянами у відношенні до фальшувальників та їх продукції, прослідковано нами як ще однин із прикладів використання надбань філології у дослідженнях спеціальних історичних дисциплін, основні 3 яких було вдало визначено О. Огуєм (Огуй, 2003: 105).

Розглянемо детальніше кожне з видів джерел. Безумовно, одним із найбільш цінних та інформативних джерел у нумізматичних дослідженнях є самі монети. Нумізматику в системі спеціальних (допоміжних) історичних джерел I. Войцехівська визначає як галузь, завданням якої є вивчення окремих типів та видів джерел, у даному випадку - монет (Войцехівська, 2001: 265). Монети належать до речових нумізматичних джерел (Калакура, 2002: 176).

Високу привабливість для фальшивомонетників мали i паперові грошові знаки - крелитні білети та асигнації через їх високу номінільну ціну. Хоча до нашого часу їх достатньої кількості не збереглось. Навіть у колекції найбільшого російського музею - Державного Ермітажу, фондова колекція якого може бути охарактеризована як достатньо вивчена, зберігачем групи паперових грошових знаків М. Маршак виявлено та заінвентаризовано лише 13 тогочасних підробок різних банкнот, що отримано музеєм 3 приватної колекції Г.Н. Ліхачова. У зібранні Національного музею історії України нам вдалось виявити підробки паперових грошових знаків лише в період після розвалу Російської імперії (Бойко-Гагарін, Родіонова, 2018: 22-25).

Невід'ємним джерелом вивчення обраної теми $є$ Законодавча база - найбільш повне Повне зібрання Законів Російської імперії, що вперше побачило світ у 1830 р. та містить всі накази, постанови та маніфести російської влади населенню країни, у тому числі і свідчення про регуляцію фінансової діяльності і грошового обігу. Враховуючи те, що обсяг всіх томів зазначеного видання досить об'ємний, відомим російським нумізматом М. Деммені було опубліковано витяг, що охоплює лише ті законодавчі акти, що стосуються монетної справи i, в тому числі, покарань за фальшивомонетництво (Деммени, 1887). 
Архівні зібрання в Україні пережили низку потрясінь, перевезень, пожеж та знищень, що суттєво вплинуло на кількість збережених до сьогодні справ. Вагомий інформаційний потенціал особових архівів відмічено А. Санцевичем (Санцевич, 1989: 95-96).

Найбагатшим архівом, що зберігає найбільшу кількість справ, часто протягом історії існування архіву з інших регіонів $\epsilon$ Центральний державний істрчиний архів України у Києві, зібрання якого налічує понад 1600 фондів (Калакура, 2002: 135). Справи про покарання, переслідування та затримання фальшивомонетників нами виявлено у фондах 3 циркулярами губернаторів, міщанських управлінь, тюремних інспекцій, міських магістратів, судів, органів прокуратури, більшість 3 яких у свій час проходить по секретній частині, надаючи справам виявлення та знешкодження фальшивомонетників державного значення.

Безперечним джерелом дослідження історії грошового обігу будь-якого регіону та історичного періоду є скарби, що неодноразово підтверджувалось відомими дослідниками, зокрема підсумки та перспективи дослідження скарбознавства всебічно та якісно представлено В. Коцуром (Коцур, 2013: 3), окресливши також основні напрямки та актуальні проблеми скарбознавства в Україні (Коцур, 2017: 15-32).

Достовірних свідчень про знахідки скарбів, що складались би із суцільних фальшивих монет в досліджуваний період серед опрацьованих джерел невідомо. Непідтвердженими виявились свідчення затриманого за збут фальшивих кредитних 25 руб. білетів у Катеринославі громадянина на прізвище Радиш, який заявив, що ніби сховав 20000 руб. готовими підробками у валянок у миловарні, що належала його батьку, чого не вдалось відшукати поліції (Южная Копейка, 1911: 2). Причиною заховування фальшивомонетниками власної продукції у ящику став «монетний голод» внаслідок нестачі обігових монет під час Першої Світової війни (Орлик, Бойко-Гагарін, 2017: 143-164), що ускладнило збут і зловмисники лишили сховати виготовлені монети номіналом у 20 коп. (Черниговское слово, 1915: 4). Тому причиною гіпотетичної появи та виявлення скарбу із 
тогочасними підробками монет чи кредитних білетів свідчитиме лише про те, що їх заховав сам фальшивомонетник, намагаючись приховати речові докази, але сподіваючись, що його діяльність зможе згодом відновитись збутом цих підробок в майбутньому.

Високим ступенем достовірності характеризуються предмети нумізматики та боністики, що зберігаються у колекціях державних музеїв. Найбільш ранню згадку про наявність фальсифікатів монет у складі музейних зібрань знаходимо в описі колекції Музею Вітебської вченої архівної комісії, складеного 1911 р. К. Змигродським - в описі музейної колекції вказано про наявність фальшивих 50 коп. 1900 р. та руб. 1899 та 1901 рр. (Змигродзкий, 1911). Враховуючи те, що монет державного карбування в ці роки було виготовлено значну кількість та на колекційному ринку вони не $є$ рідкісними, можна припустити, що в даному описі фігурують не антикварні підробки рідкісних різновидів монет, а тогочасні підробки. На жаль, більшість вивчених підробок того часу в музейних зібраннях не було зафіксовано місць та обставин знахідки підробок, інвентарні книги та книги вступу 3 інформацією про походження монет у музейній колекції свідчать про передачі більшості цих монет із колекцій приватних осіб, що на сьогоднішній день вже унеможливлює додавання таких монет у топографію знахідок та можливості здійснення додаткових висновків щодо цих екземплярів тощо.

Цікавим $є$ питання обліку та зберігання тогочасних підробок монет у музейних колекціях. Виходячи із того, що облік предметів із дорогоцінних та недорогоцінних металів ведеться у музеях окремо, а переважна більшість фальшивих монет виготовлена із недорогоцінного металу лише 3 подальшим покриттям тонким шаром дорогоцінного, записи щодо отримання подібних монет ведеться у інвентарних книгах щодо обліку монет із недорогоцінних металів. Ті ж підробки, що за результатами проведення апробації та встановлення вмісту срібла чи золота у їх складі, обліковуються в основному фонді разом із оригінальними монетами із дорогоцінними металами. В окрему групу старі зберігання приватні підробки не виносяться. Вважаємо, що таку категорію монет (так само 
як і банкнот та грошових сурогатів), як старі приватні підробки, виготовлені для нанесення збитку грошовому обігу та обману, необхідно виносити в окрему групу зберігання у музейних колекціях як державних, так і приватних установ. Відповідних коректив також вимагають і наявні в музеях інструкцій з обліку.

Серед коплексу допоміжних джерел, які ми використали в процесі дослідження, необхідно відзначити електронні ресурси. Погоджуючись із високою оцінкою В. Орлика інформаційного потенціалу WEB-ресурсів (Орлик, 2013: 129133), ми також підтримуємо тезу дослідниці О. Шпортун в тому, що наявність більше ніж 500 тис. сайтів з нумізматичної тематики на запит у пошуковій системі «Google» свідчить про значний інтерес аудиторії до вивчення нумізматики та популярності їі як спеціальної галузі історичної науки (Шпортун, 2016: 174-179).

В. Коцуром комплексно та влучно аргументовано необхідність введення до наукового обігу нових знахідок монет з числа приватних пошуків (Коцур, 2016: 11-14).

Окрім електронних Інтернет-аукціонів, тогочасні підробки для збитку грошового обігу трапляються i на сторінках друкованих каталогів аукціонів спеціалізованих фірм. Так на першому аукціоні «Дукат» у 2005 р. продавалась підроблена за ініціативи Наполеона I російська банкнота номіналом 25 руб. зразка 1811 р. із № 50220, імовірніше за все, виявлена у складі старої приватної колекції в Україні (Нумізматичний аукціон «Дукат», 2005).

Задоволення інформаційних потреб сучасних науковців щорічно зростає через використання електронних бібліотечних ресурсів, упровадження комп'ютерних технологій, створення електронних каталогів, повнотекстових баз даних, віртуальних та мультимедійних електронних бібліотек (Супруненко, 2012: 651-653). Електронні версії путівників по державних історичних архівах України завантажено у вільний доступ на сайті Державного комітету архівів України, маючи також прямі покликання на офіційні Інтернет-сторінки всіх державних історичних архівів областей України, що містять інформацію про склад та структуру фондів (Кисельова, 2004: 484-499). 
Окрім державних бібліотек, як історично сформованих документальних масивів широкого профілю, що об’єднують ряд окремо виділених колекцій чи фондів, вагомим інформаційним потенціалом та можливістю ознайомлення із рідкісними виданнями вузького профілю дозволяють приватні книжкові зібрання та колекції, що зазвичай об'єднані у вузьку тематику (Лисенко, 2003: 220-221). Так в процесі підготовки дисертації нами досліджено приватні книгозбірні В. Орлика, Л. Дергачьової, М. Котляра (видання з нумізматики передані вченим до Національного музею історії України), М. Моїсеєнко та ін.

Наводячи класифікацію джерел, Я. Калакурою охарактеризовано газетні видання як такі, що: «/.../ є основним носієм інформації, особливо з новітньої історії.» (Калакура, 2002: 111). Незважаючи на притаманні газетним виданням недоліки, $з$ цим твердженням важко не погодитись.

Українські газети у фондах Національної бібліотеки України ім. В.I. Вернадського представлені 31818 р., нараховують більше 200 тис. річних комплектів. До 1917 р. в Україні видавалось близько 1200 найменувань газет, 3 яких більше 320 найменувань збережені у фонді Національної бібліотеки України ім. В. І. Вернадського та доступні для дослідників (Офіційний сайт Національної бібліотеки України iм. В. I. Вернадського). Газетна періодика - надзвичайно цінне історичне джерело. Під час IV Республіканської наукової конференції з історичного краєзнавства, що відбулась у Києві у 1989 р., вітчизняними науковцями високо оцінений потенціал використання періодичної преси у багатьох напрямках історичних досліджень. Під час цієї конференції відомими українськими вченими Віктором та Анатолієм Коцурами надано високу оцінку використанню української місцевої преси в дослідженнях питання відбудови народного господарства України у 1921-1925 pp.

Головним недоліком інформації, що міститься в газетній періодиці, часто виявляється іiі неповнота та поверхове відображення, інколи навіть із вмістом явно неправдивих свідчень і технологій «чорного піару». Причини цього криються в основному спрямуванні газетної періодики певного 
періоду - поширення інформації серед широких мас населення, подання iï у доступному вигляді, без заглиблення в деталі (часто дуже важливі для сучасних дослідників), нерідко 3 використанням технологій впливу, а також те, що в редакторів та репортерів газет досить часто спостерігається відсутність спеціальних знань стосовно вузьких галузей суспільного життя та нехтування при цьому необхідності звернутися за консультацією до професіоналів. Яскравим прикладом досить малої інформативності газетних повідомлень є опублікована у газеті «Киевские Отклики» замітка лише на 2 рядки: «Фальшивомонетники. Одеса. 2. Виявлено фабрику фальшивих срібних монет» (Киевские отклики, 1911: 3), а також замітка в газеті «Южная Копейка» і лише 3 рядки: «Фальшивомонетник. Катеринодар. Виявлена фабрика фальшивих срібних монет. Троє заарештовані» (Южная копейка, 1911: 4). Звісно ж такі повідомлення не мають вагомої історичної цінності та новизни. Враховуючи велику кількість повідомлень суто загального характеру, ми припускаємо, що частина повідомлень газет могли мати суттєві неточності або розміщувались на сторінки газет з метою привернення уваги як «гарячі» заголовки. Яскравим прикладом використання заголовку щодо фальшивомонетників як маркетингового інструменту знаходимо в газеті «Киевские Вести» від 4 грудня 1907 р., що повідомляє: «Фальшиві гроші мають точно таку саму цінність, як і підроблені Соденські Тістечка. Тому слід завжди виразно вимагати справжні Соденські мінеральні тістечка Фая, адже лише ті в дійсності виготовлені 3 випаровування 3 відомих у всьому світі Соденських цілющих джерел № 3 та № 18 в сутності дійсно справжніх» (Киевские Вести, 1907: 1). Але, в той же час, така замітка свідчить про широку відомість наявності на ринку фальшивих монет, що хвилювало населення та привертало увагу, адже отримання інформації про появу фальшивих грошей та їх характерні ознаки могла заощадити на потенційних збитках.

Явище фальшування монет було настільки поширене та суспільство проінформоване про цей вид небезпеки, що деякі газетні видання навіть ставились до цього 3 гумором, публікуючи анекдоти: «В аптеці. - Який негідник! Він сплатив 
нам за ліки 27 копійок, а дав фальшивий двогривенний. Імовірно, цей чоловік ще недалеко і йому їх можна повернути! - Не варто. Все ж таки, у нас лишилось чистого баришу 6 копійок» (Листок-Копейка, 1912: 2). Таким чином в газеті піднімалось також питання надмірних цін на аптекарські товари, адже продані особою, що займається збутом фальшивих монет, ліки були продані за 27 копійок при собівартості лише в одну.

Інколи шпальти газет занадто романтизують історії фальшивомонетників, що може наштовхнути на думку про часткову вигаданість наведених заміток. Так львівська газета «Діло» повідомляє про самогубство чоловіка та жінки, що намагались збути у Відні фальшиву банкноту у 10 гульденів: «/.../ она вибегла на улицю, де муж ждав на ею. Поліція обоєх їх увязнила, але коли їх праведено до комнати інспекційной, оба упаля на землю отруївшися» (Діло, 1895: 3).

Під час вивчення газетних матеріалів 3 метою пошуку свідчень про підробки монет та банкнот у досліджуваний період ми відстежили деякі дані щодо методичної складової пошуку та потрапляння подібних свідчень на шпальти газет. Найчастіше повідомлення про появу фальшивих грошей трапляються на третій сторінці видання, публікації повідомлень про фальшиві гроші нам не зустрічались на перших сторінках у найважливіших новинах. Подібні повідомлення, зазвичай, описані редакторами газет у рубриках загальних новин, або, у деяких виданнях, у спеціальній рубриці кримінальних подій. Газети Галичини кін. XIX - поч. XX ст. часто звинувачують єврейське населення у всіх негативних явищах, що трапились у регіоні, в тому числі щодо фактів виявлення підробок грошей.

Враховуючи той факт, що на сьогодні нами не було виявлено відповідностей серед опублікованих у газетах свідчень 3 матеріалами архівів та наявних підробок монет у приватних та музейних колекціях, можна припустити, що певна частина повідомлень у періодичній пресі (особливо мало деталізованих і написаних узагальнено), могли насправді не відбуватись, а публікувались 3 метою наповнення видань цікавими для населення фактами. 
Вважаємо, що збережені у колекціях музеїв старі газети також можуть бути ефективно використані у побудові експозицій та тимчасових виставок, доповнюючи їх. Окремі номери газет, що містять свідчення про підробку грошей, можуть якісно доповнити тематичні виставки, присвячені історії фальсифікації грошей в регіоні.

Дослідниця О. Ковалевська вдало визначає фотографію 3 однієї сторони як предмет дослідження, а з іншої - як метод (Ковалевська, 2018: 119). У фокусі дослідження процесів фальшування монет характерним є обидва види використання фотографії - збережені у фондах державних історичних архівів фотографії фальшивомонетників спрошують складання їх соціального портрету. Так у фондах Державного архіву Київської області збережено справи Київської губернської тюремної інспекції, що містять фотокартки фальшивомонетників (ДАКО. Ф. 7. Оп. 5. Спр. 1129).

У кінці XIX ст. у Російській імперії виникає кінематограф, стає доступним кіно (Ковалевська, 2018: 126). На противагу тому, що практики сьогодення часто застосовують відео-зйомку у процесі слідства над фальшивомонетниками, відео-фіксації викриття місць незаконного виробництва підробок та ін., в досліджуваному періоді нам не вдалось зафіксувати збережені відеофайли.

Висновки. Отже, розкриття теми вивчення процесів фальшування монет в Україні в імперську добу можливе шляхом дослідження низки речових, зображальних, поведінкових та писемних джерел. Основним речовим джерелом у вивченні обраної теми є збережені до нашого часу тогочасні підробки монет та банкнот. У свою чергу ці артефакти зберігаються у музейних зібраннях та приватних, інколи містяться у архівних справах як речові докази. Високу цінність та вагомий потенціал у вивченні теми фальшування грошей мають державні архіви, сторінки справ яких розкривають найрізноманітніші аспекти досліджуваного виду злочину у вказаний період. Хоча газетній періодиці i притаманні деякі недоліки, повідомлення на шпальтах імперської преси розширюють наше уявлення про процеси підробки грошей. Опубліковані праці попередніх дослідників 
зберігаються у фондах бібліотек, а також у приватних книгозбірнях, завантажені у Інтернет-бази та ресурси, що також стають в нагоді при вивченні теми. Продані фальшиві монети на нумізматичних аукціонах зафіксовані у відповідних каталогах продажів. Додаткові дані надають дослідникам фотота відео-матеріали.

\section{ДЖЕРЕЛА ТА ЛІТЕРАТУРА}

1. Державний архів Київської області. Ф. 7. (Фонд «Київська тюремна інспекція»). Оп. 5. Од. зб. 1129. 34 арк.

2. В аптеке. Листок-Копейка. Еженедельный юмористический журнал. № 142. Санкт-Петербург, 1912. С. 2.

3. Фабрика фальшивых кредиток. Южная Копейка. №. 28 апреля. Киев, 1911. С. 2.

4. Фальшивомонетчик. Южная копейка. № 196. 24 июня. Киев, 1911. С. 4.

5. Фальшивомонетчики. Киевские отклики. № 292. 2 декабря. Киев, 1911. С. 3.

6. Фальшовники грошей. Діло. Ч. 274. 8 (20) грудня. Львов, 1895. C. 3.

7. Фальшывыя деньги. Киевские Вести. № 171. 4 (17) декабря. Киев, 1907. С. 1.

8. Ящик фальшивомонетчиков. Черниговское слово. № 2575. 20 ноября. Чернигов, 1915. С. 4.

9. Kotsur V., Boiko-Gagarin A. Napoleon russian forged assignations in Naddniprianshchyna (over Dnipro land) // East European historical bulletin. Drohobych, 2019. Issue 11. P. 66-77.

10. Бойко-Гагарін А., Родіонова О. Тогочасні підробки 100 карбованців 1917 року у колекції НМІУ // Нумізматика і фалеристика. Київ, 2018. № 3. С. 22-25.

11. Войцехівська I. Структура історичного джерелознавства: традиції та сучасні проблеми // Міжвідомчий збірник наукових праць. Архівознавство археографія Джерелознавство. Джерелознавчі дисципліни. Київ, 2001. Вип. III. С. 265.

12. Деммени М. Сборник указов по монетному и медальному делу в России, помещенных в Полном Собрании Законов с 1649 по 1881 г. С.-Петербург: Издание Вел. Кн. Георгия Михайловича, Выпуск 1. 1887. 
13. Змигродзкий К.А. Каталог монет и медалей Музея Витебской ученой архивной комиссии. Витебск: Типография насл. М.Б. Неймана, 1911.

14. Калакура Я.С., Войцехівська I.Н. Історичне джерелознавство: підручник для студентів історичних спеціальностей вищих навчальних закладів. Київ: Либідь, 2002. $488 \mathrm{c}$.

15. Кисельова А. Веб-сайт Державного комітету архівів України: загальний огляд структури змісту // Наукові праці Національної бібліотеки України ім.В.І.Вернадського. Київ, 2004. Випуск 13. С. 484-499.

16. Ковалевська О. Візуальні студії. Нариси 3 соціокультурної історії українського історієписання: субдисциплінарні напрями: колект. Монографія - Удод О., Веременич Я. та ін. Ін-т історії України. Київ: Генеза, 2018. C. 119.

17. Колобова, И. Н. (2015) Материалы Национального исторического архива Беларуси о деятельности фальшивомонетчиков XIX в. // Studia i Materialy Pieniadz a propaganda. Wspolne dziedzictwo Europy. Augustiow-Warszawa, pp. 208.

18. Коцур В.П. Актуальні напрямки та організаційні засади сучасних досліджень середньовічної нумізматики в Україні // Наукові записки з української історії: Збірник наукових статей. Переяслав-Хмельницький, 2013. Вип. 33. С. 3.

19. Коцур В.П. Історіографія українського скарбознавства // Український Нумізматичний Щорічник. Київ, 2017. № 1. C. 15-32.

20. Коцур В.П. Щодо проблеми використання матеріалів «чорної» археології в наукових дослідженнях з нумізматики // Тези доповідей IV міжнародної науково-практичної конференції «Актуальні проблеми нумізматики у системі спеціальних галузей історичної науки». 22-23 червня 2016 р. Кіровоград-Київ-Переяслав-Хмельницький, 2016. С. 11-14.

21. Лисенко Л.В. Наукові категорії «колекція», «зібрання», «бібліотека» як об'єкт вивчення, опису та реставрації: до проблеми класифікації понять // Рукописна та книжкова спадщина України. Археографічні дослідження унікальних 
архівних та бібліотечних фондів. Київ, 2003. Випуск 8. C. $220-221$.

22. Нумізматичний аукціон «Дукат». Монети і бони України і світу. 23 квітня 2005 р. \# 1. Лот 209. Київ, 2005.

23. Огуй О.Д. Спеціальні історичні дисципліни та філологія: місця дотику та визначення методології пошуків // Спеціальні історичні дисципліни: питання теорії та методики. Збірка наукових праць пам'яті відомого вченого-історика доктора історичних наук Михайла Брайчевського. Київ, 2003. Число 10. Частина 1. С. 105.

24. Орлик В. Сгор Канкрін і фіскальна політика Російської імперії в Правобережній Україні в другій чверті XIX ст. // Спеціальні історичні дисципліни: питання теорії та методики. 2006. No 13. C. 97-110.

25. Орлик В.М. Дожовтнева фінансово-правова література як джерело до вивчення проблем фінансової політики уряду Російської імперії кінця XVIII початку XX ст. Історія науки і біографістика. 2010. No 2. URL: http://www.nbuv.gov.ua/ejournals/INB/2010-2/10_orlyk.pdf

26. Орлик В.М. До питання методології досліджень проблем економічної історії Російської імперії // Проблеми історії України XIX початку XX ст. 2011. No 18. С. 59-64.

27. Орлик B.M. Інформаційний потенціал WEB-ресурсів у нумізматичних дослідженнях (на прикладі монет держав Хрестоносців). Матеріали наукової конференції $з$ міжнародною участю. Архівознавчі та джерелознавчі галузі знань: проблеми взаємодії на сучасному етапі. 14 березня 2013 р. Київ, 2013. C. $129-133$.

28. Орлик С.В., Бойко-Гагарін А.С. Фальшивомонетництво в Україні в роки Першої світової війни // Український нумізматичний щорічник. Переяслав-Хмельницький, 2017. № 1. С. 143-164.

29. Орлик, С. В. (2018) Российские фальшивые кредитные билеты в Галиции в годы Первой мировой войны // Банкаускі Веснік. Минск, (2). 51-54.

30. Орлик, С. В. (2018) Фінансова політика російського окупаційного режиму в Галичині та Буковині в роки Першої світової війни (1914-1917 рр.). Автореф. дис. ... Д-ра іст. наук: спец. 07.00.02. Київ, 2008. 35 с. 
31. Орлик, С. В. (2018) Фінансова політика російського уряду на окупованих територіях Галичини і Буковини в період Першої світової війни (1914-1917рр.): монографія. Біла Церква: Вид. Пшонківський О. В., 716 с.

32. Орлик, С. В.; Бойко-Гагарін, А. С. (2017) Фальшивомонетництво в Україні в роки Першої світової війни // Український нумізматичний щорічник. Київ, № 1. C. 143-164.

33. Санцевич А.В. Роль особових архівних фондів у краєзнавчій роботі // Тези доповідей і повідомлень «IV республіканська конференція 3 історичного краєзнавства». Київ, 1989. С. 95-96.

34. Супруненко C.I. Електронні бібліотеки в Україні: створення, розвиток та використання // X Культурологічні читання пам’яті Володимира Подкопаєва «Українська культура: виклики сьогодення». м. Київ, 31 травня - 1 червня 2012 р. К.: НАККІМ, 2012. С. 651-653.

35. Тимошина, Н. Н. (2015) О фальшивомонетничестве начала XIX в. по воспоминаниям Владимирского губернатора, князя И.М.Долгорукова // Тезисы докладов и сообщений. Восемнадцатая Всероссийская нумизматическая конференция. Москва-Коломна. 20-25 апреля 2015 г. Москва, 2015. С. 200.

36. Шпортун О. Нумізматичні веб-сайти України // Studia I Materialy «Forum Numizmatyczne, Pieniadz I Mennice». Bialystok, 2016. № 1. S. 174-179.

37. Офіційний сайт Національної бібліотеки України ім. B.I. Вернадського. Відділ газетних фондів. URL: http://www.nbuv.gov.ua/node/70 (дата звернення: 20.01.2018).

\section{REFERENCES}

1. Boiko-Haharin, A.S. \& Rodionova, O.S. (2018). Tohochasni pidrobky 100 karbovantsiv 1917 roku u kolektsii NMIU [The forgeries of the 100 karbovanets of 1917 in the collection of NMHU]. Numizmatyka i falerystyka, 3, 22-25 [in Ukrainian].

2. Demmeni, M. (1887). Sbornik ukazov po monetnomu $i$ medal'nomu delu $v$ Rossii, pomeshhennyh $v$ Polnom Sobranii Zakonovs 1649 po $1881 \mathrm{~g}$. [A collection of decrees on monetary and medal business in Russia, placed in the Complete Collection of Laws from 1649 to 1881], 1 [in Russian]. 
3. Kalakura, Ya.S. \& Voitsekhivska, I.N. (2002). Istorychne dzhereloznavstvo. Pidruchnyk dlia studentiv istorychnykh spetsialnostei vyshchykh navchalnykh zakladiv [Historical source studies. A textbook for students of historical specialties of higher education]. Kyiv: Lybid [in Ukrainian].

4. Kolobova, I.N. (2015) Materialy Nacional'nogo istoricheskogo arhiva Belarusi o dejatel'nosti fal'shivomonetchikov XIX v. [The materials of the National historical archieve of Belarus about the activity of the money counterfeiters in XIX cent.]. Abstract of papers. Pieniadz a propaganda. Wspolne dziedzictwo Europy. Augustiow-Warszawa [Money and propaganda. A shared heritage of Europe], 208 [in Russian].

5. Kotsur, V. \& Boiko-Gagarin, A. (2019). Napoleon russian forged assignations in Naddniprianshchyna (over Dnipro land). East European historical bulletin. Issue 11. Drohobych, 66-77 [in Ukrainian].

6. Kotsur, V.P. (2013). Aktualni napriamky ta orhanizatsiini zasady suchasnykh doslidzhen serednovichnoi numizmatyky $\mathrm{v}$ Ukraini. [Actual directions and organizational foundations of modern researches of medieval numismatics in Ukraine]. Naukovi zapysky z ukrainskoi istorii, 33, 3 [in Ukrainian].

7. Kotsur, V.P. (2016). Shchodo problemy vykorystannia materialiv «chornoi» arkheolohii v naukovykh doslidzhenniakh z numizmatyky. [To the problem of use of the materials of the black archeology in the numismatic research] Abstract of papers: Aktualni problemy numizmatyky u systemi spetsialnykh haluzei istorychnoi nauky, 11-14) [in Ukrainian].

8. Kotsur, V.P. (2017). Istoriohrafiia ukrainskoho skarboznavstva [The historiography of the Ukrainian treasureology]. Ukrainskyi Numizmatychnyi Shchorichnyk, 1, 1532 [in Ukrainian].

9. Kovalevska, O. (2018). Vizualni studii. Narysy z sotsiokulturnoi istorii ukrainskoho istoriiepysannia: subdystsyplinarni napriamy [Visual Studios. Essays on the Socio-Cultural History of Ukrainian Historical Writing: Subdisciplinary Directions]. Kyiv: Heneza, 119 [in Ukrainian].

10. Kyselova, A. (2004). Veb-sait Derzhavnoho komitetu arkhiviv Ukrainy: zahalnyi ohliad struktury zmistu. [State Archives Committee of Ukraine website: overview of content structure]. 
Naukovi pratsi Natsionalnoi biblioteky Ukrainy im.V.I.Vernadskoho, 13, 484-499 [in Ukrainian].

11. Lysenko, L.V. (2003). Naukovi katehorii «kolektsiia», «zibrannia», «biblioteka» yak obiekt vyvchennia, opysu ta restavratsii: do problemy klasyfikatsii poniat [Scientific categories «collection», «collections», «library» as objects of study, description and restoration: to the problem of classification of concepts]. Rukopysna ta knyzhkova spadshchyna Ukrainy. Arkheohrafichni doslidzhennia unikalnykh arkhivnykh ta bibliotechnykh fondiv, 8, 220-221 [in Ukrainian].

12. Numizmatychnyi auktsion «Dukat», (2005). Monety i bony Ukrainy i svitu. 23 kvitnia 2005 r. \# 1. Lot 209. [Numismatic Dukat Auction, (2005). Coins and notes of Ukraine and the World. April 23, 2005 \# 1. Lot 209]. Kyiv [in Ukrainian].

13. Ohui, O.D. (2003). Spetsialni istorychni dystsypliny ta filolohiia: mistsia dotyku ta vyznachennia metodolohii poshukiv [Special historical disciplines and the philology: touches and definition of the search methodology]. Spetsialni istorychni dystsypliny: pytannia teorii ta metodyky, 10, 105 [in Ukrainian].

14. Orlik, S.V. (2018). Rossijskie fal'shivye kreditnye bilety v Galicii v gody Pervoj mirovoj vojny [Russian fake credit tickets in Galicia during the First World War]. Bankauski Vesnik, 2, 51-54 [in Russian].

15. Orlyk, S.V. (2018). Finansova polityka rosiiskoho okupatsiinoho rezhymu v Halychyni ta Bukovyni v roky Pershoi svitovoi viiny (1914-1917 rr.). [Financial policy of the Russian occupation regime in Galicia and Bukovina during the First World War (1914-1917)]. (Extended abstract of Doctors thesis). Kyiv [in Ukrainian].

16. Orlyk, S.V. (2018). Finansova polityka rosiiskoho uriadu na okupovanykh terytoriiakh Halychyny i Bukovyny v period Pershoi svitovoi viiny (1914-1917 rr.). [Financial Policy of the Russian Government in the Occupied Territories of Galicia and Bukovina during the First World War (1914-1917)]. Bila Tserkva: Pshonkivskyi O. V., 716 [in Ukrainian].
17. Orlyk,
S.V.\&
Boiko-Haharin,
A. S. (2017).

Falshyvomonetnytstvo v Ukraini v roky Pershoi svitovoi viiny [The money counterfeit during the WWI]. Ukrainskyi numizmatychnyi shchorichnyk, 1, 143-164 [in Ukrainian]. 
18. Orlyk, V.M. (2006). Yehor Kankrin i fiskalna polityka Rosiiskoi imperii v Pravoberezhnii Ukraini v druhii chverti XIX st. [Yegor Kankrin and the fiscal policy of the Russian Empire in Right-Bank Ukrainein the second quarter of the nineteenth century]. Spetsialni istorychni dystsypliny: pytannia teorii tametodyky [Special Historical Disciplines: Theory and Methodology]. 13. Nats. akad. nauk Ukrainy, In-t istorii Ukrainy, 97-110 [in Ukrainian].

19. Orlyk, V.M. (2013). Informatsiinyi potentsial WEB-resursiv u numizmatychnykh doslidzhenniakh (na prykladi monet derzhav Khrestonostsiv) [Information potential of WEB resources in numismatic studies (on the example of the coins of the Crusader states)]. Abstracts of papers: Arkhivoznavchi ta dzhereloznavchi haluzi znan: problemy vzaiemodii na suchasnomu etapi, 129-133 [in Ukrainian].

20. Orlyk, V.M. (2010). Dozhovtneva finansovo-pravova literatura yak dzherelo do vyvchennia problem finansovoi polityky uriadu Rosiiskoi imperii kintsia XVIII pochatku XX st. [The Prerevolutionary financial and legal literature as a source for studying the problems of the financial policy of the government of the Russian Empire in the late18th early 20th century]. Istoriia nauky $i$ biohrafistyka [History of Science and Biografistica]. Retrieved from http://www.nbuv.gov.ua/e-journals/INB/20102/10_orlyk.pdf [in Ukrainian].

21. Orlyk, V.M. (2011). Do pytannia metodolohii doslidzhen problem ekonomichnoi istorii Rosiiskoi imperii [On the question of the methodology of research on the problems of the economic history ofthe Russian Empire]. Problemy istorii Ukrainy XIX pochatku XX st. [The problems of the History ofUkraine of the 19th and early 20th centuries], 18, 59-64 [in Ukrainian].

22. Santsevych, A.V. (1989). Rol osobovykh arkhivnykh fondiv $\mathrm{u}$ kraieznavchii roboti [The role of the personal archieval funds in the history working]. Abstracts of papers: IV respublikanska konferentsiia z istorychnoho kraieznavstva, 95-96 [in Ukrainian].

23. Shportun, O. (2016). Numizmatychni veb-saity Ukrainy [The numismatical WEB-sites of Ukraine]. Forum Numizmatyczne, Pieniadz I Mennice, 1, 174-179 [in Ukrainian].

24. Suprunenko, S.I. (2012). Elektronni biblioteky v Ukraini: stvorennia, rozvytok ta vykorystannia [The electronic libraries in 
Ukraine: the creation, development and usage]. Abstracts of papers: X Kulturolohichni chytannia pamiati Volodymyra Podkopaieva «Ukrainska kultura: vyklyky sohodennia», 651-653 [in Ukrainian].

25. Timoshina, N.N. (2015). O fal'shivomonetnichestve nachala XIX v. po vospominanijam Vladimirskogo gubernatora, knjazja I.M. Dolgorukova [About counterfeiting of the beginning of the 19th century according to the memoirs of the Vladimir governor, Prince I.M. Dolgorukov]. Abstract of papers. Vosemnadcataja Vserossijskaja numizmaticheskaja konferencija. [The eighteens allRussian numismatic conference], 200. [in Russian].

26. Voitsekhivska, I. (2001). Struktura istorychnoho dzhereloznavstva: tradytsii ta suchasni problemy [The structure of the historical source studying: the traditions and the modern problems]. Arkhivoznavstvo arkheohrafiia Dzhereloznavstvo, 3, 265 [in Ukrainian].

27. Zmigrodzkij, K.A. (1911). Katalog monet i medalej Muzeja Vitebskoj uchenoj arhivnoj komissii [The catalogue of the coins and medals of the Vitebsk scientific archieval comission Museum]. Tipografija M.B. Nejmana [in Russian].

\section{АНОТАЦІЯ}

Розкриття теми вивчення процесів фальшування монет в Украйні в імперську добу можливе шляхом дослідження низки речових, зображальних, поведінкових та писемних джерел. Основним речовим джерелом у вивченні обраної теми $\epsilon$ збережені до нашого часу тогочасні підробки монет та банкнот. В свою чергу иі артефакти зберігаються в музейній та приватних зібраннях, інколи в якості речових доказів містяться вшитими як окремі аркуші в кримінальних справах, збережених в архівах. Високу иінність та вагомий потенціал у вивченні теми фальшування грошей мають державні архіви, сторінки справ яких розкривають найрізноманітніші аспекти досліджуваного виду злочину у вказаний період. Хоча газетній періодиці $і$ притаманні деякі недоліки, повідомлення на шпальтах імперської преси розширюють уявлення про прочеси підробки грошей. Опубліковані прачі попередніх дослідників зберігаються у фондах бібліотек, а також у приватних книгозбірнях, завантажені в Інтернет-бази та ресурси, особисті сторінки сочіальних мереж науковиів, також 
стають у нагоді при вивченні теми. Продані фальшиві монети на нумізматичних аукиіонах зафіксовані в відповідних каталогах продажів. Додаткові дані надають дослідникам фото та відео-матеріали, збережені в дежавних історичних apxiвax.

Ключові слова: Російська імперія, фальшування грошей, методологія дослідження прочесів фальшування монет, архівні матеріали, музейні колекиії.

\section{АННОТАЦИЯ}

Раскрытие темь изучения процессов фальшивомонетничества в Украине в империалистическою эпоху возможно путем исследования ряда вещуественных, художественных, поведенческих, а также письменных источников. Основным вещественныл источником в изучении выбранной темы являются сохраненные до нашего времени подделки монет и банкнот того периода. В свою очередь эти артефакты хранятся в музейных собраниях, а также частных коллекциях, иногда содержатся в архивных делах в качестве вешественных доказательств, вииты как отдельные листы в криминальных делах. Высокую иценность и весомый потенциал в изучении тематики подделки денег имеют государственные архивы, странищь дел которых раскрывают наиболее разнообразные аспекты исследуемого вида преступения в указанный период. Хотя газетной периодике и свойственнь некоторые недостатки, сообщения на страницах имперской прессы расширяют представление о процессах подделки денег. Опубликованные труды предидущчих исследователей сохраняются в фондах библиотек, а также в частных собраниях книг, выгружены в интернет-базы и ресурсы, личные страници в сочиальных сетях для научных сотрудников, которые также актуальны при изучении темы. Проданные фальшивые монеть на нумизматических аукиионах зафиксированы в соответствуюших каталогах продаж. Дополнительные данные предоставляются исследователям фото и видео-материалами, сохраняемые в государстыенных исторических архивах.

Ключевые слова: Российская империя, подделка денег, методология исследования прочеесов подделки денег, архивные материаль, музейные коллекции. 